\title{
ECHOCARDIOGRAPHIC EFFECTS OF ADHERENCE TO PHYSICAL EXERCISE IN OLDER ADULTS: RESULTS FROM THE AGA@4LIFE COHORT
}

\author{
Efeitos ecocardiográficos da adesão a exercícios \\ físicos em idosos: resultados da coorte AGA@4life
}

\author{
Joaquim Castanheira ${ }^{\circledR}$, Ana Carolina Carvalho ${ }^{\circledR}$, Telmo Pereira ${ }^{\circledR}($
}

INTRODUCTION: Aging is associated with changes in heart structure and function, and there are benefits of physical exercise in delaying these changes. OBJECTIVES: To characterize the heart of a geriatric cohort at a structural and functional level, and to evaluate the potential cardiac benefits of a personalized exercise intervention program. METHODS: Non-randomized intervention study, including a group of old adults from the AGA@4life cohort. Two echocardiographic evaluations were performed, at baseline and 3 months after the implementation of a multidisciplinary intervention program, integrating the practice of adapted physical exercise. Participants were divided into 2 groups: group 1 with low adherence to the exercise program (<20\% of sessions); group 2 with high adherence to the exercise program (> 90\% of sessions). RESULTS: Characteristic heart changes were observed at baseline, mainly at the valvular level, with $89.2 \%(n=33)$ cases of aortic fibrosis, $73 \%(n=27)$ cases of mitral fibrosis, $51.2 \%(n=19)$ cases of aortic regurgitation, and $68 \%(n=25)$ cases of mitral regurgitation. After the intervention, significant changes were observed in several functional parameters in group 2, namely in the maximum velocity of the $E^{\prime}(p=0.01)$ and $S^{\prime}(p=0.02)$ mitral valve waves, and maximum velocity of the $E^{\prime}$ tricuspid valve wave $(p=0.02)$. Positive structural changes were also observed in group 2 , namely a reduction in relative wall thickness ( $p=0.03)$ and left ventricular diastolic diameter $(p=0.04)$. CONCLUSION: Personalized physical exercise implemented as part of a multidisciplinary intervention program is a useful non-pharmacological tool for maintaining adequate cardiac function and structure in the old adult.

KEYWORDS: aging; heart; echocardiography; physical exercise.

INTRODUÇÃO: O envelhecimento associa-se a alterações na estrutura e função do coração, havendo benefícios da prática de exercício físico no retardamento dessas alterações. OBJETIVOS: Caracterizar as alterações ecocardiográficas de uma população idosa submetida à intervenção multidisciplinar incluindo programa de exercício físico adaptado e avaliar as diferenças entre os melhores e piores níveis de adesão à atividade física. MÉTODOS: Estudo de intervenção não randomizado com um grupo de idosos da coorte AGA@4life. Realizaram-se duas avaliações ecocardiográficas, uma basal e outra após a implementação de um programa de intervenção multidisciplinar com um componente de exercício físico por três meses consecutivos. Os participantes foram divididos em dois grupos: grupo 1, com baixa adesão ao programa de exercício físico (< 20\% das sessões); grupo 2, com elevada adesão ao programa de exercício físico (> 90\% das sessões). RESULTADOS: Na avaliação basal, identificaram-se alterações ecocardiográficas associadas ao envelhecimento - 89,2\% ( $n=33$ ) de casos com fibrose aórtica, 73\% ( $n=27)$ de casos com fibrose mitral, 51,2\% $(n=19)$ de casos com regurgitação aórtica e $68 \%(n=25)$ de casos com regurgitação mitral. Após a intervenção, verificaram-se variações significativas em diversos parâmetros funcionais no grupo 2, sobretudo nas velocidades máximas das ondas E' $(p=0,016)$ e $S(p=0,02)$ da válvula mitral e da onda E' da válvula tricúspide ( $p=0,027)$. Observaram-se ainda modificações estruturais no grupo 2 , nomeadamente redução na espessura parietal relativa $(p=0,033)$ e no diâmetro diastólico $(p=0,041)$ do ventrículo esquerdo. CONCLUSÕES: O exercício físico adaptado e implementado no âmbito de um programa de intervenção multidisciplinar constitui uma ferramenta não farmacológica útil para a manutenção de função e estrutura cardíacas adequadas no idoso.

PALAVRAS-CHAVE: envelhecimento; coração; ecocardiografia; exercício físico.

alnstituto Politécnico de Coimbra, Escola Superior de Tecnologia da Saúde de Coimbra - Coimbra, Portugal.

Corresponding data

Telmo Pereira - Instituto Politécnico de Coimbra, Escola Superior de Tecnologia da Saúde de Coimbra - Rua 5 de Outubro, ap. 7006 - SM Bispo CEP: 3046-854 - Coimbra, Portugal. E-mail: telmo@estescoimbra.pt

Received on: 09/26/2019. Accepted on: 11/22/2019

DOI: $10.5327 / 22447-212320201900074$ 


\section{INTRODUCTION}

Portugal is one of the fastest aging countries in the world, according to the United Nations World Population Prospects: The 2015 Revision. ${ }^{1}$ Aging results from an environment-modulated genetic expression ${ }^{2}$ characterized by a dynamic, progressive, and irreversible process, closely linked to biological, cognitive, and social factors. ${ }^{3,4}$ Some studies ${ }^{5-7}$ suggest a relationship between advancing age and the development of cardiovascular disease, both at the structural and functional levels, with a higher incidence for the left-sided valves. ${ }^{8-15}$

Although stroke volume and cardiac output do not change significantly in this population when compared to younger individuals, ${ }^{6,16}$ heart failure is usually present in about $5 \%$ of individuals aged 65 to 75 years, rising to $10-20 \%$ in individuals over 80 years of age. ${ }^{6}$ Due to the slower ventricular relaxation at this age, and the increased contribution of atrial systole to left ventricular (LV) end-diastolic volume, ${ }^{6,17}$ there is a reduction in diastolic function..$^{5-7,18} \mathrm{In}$ fact some authors ${ }^{7,19}$ clarify that diastolic function decreases progressively from 20 years of age (reaching $50 \%$ at 80 years), and this decrease may be associated with myocardial fibrosis phenomena. ${ }^{16}$

With aging, heart rate and contractile response to hypotension and to exercise are also reduced. ${ }^{20}$ Systemic arteries decrease their elasticity and increase stiffness (due to calcium deposition and fiber loss, leading to increased contractile strength), which leads to increased left ventricular contractility to counteract the afterload. ${ }^{17,21}$ This leads to an increase in systolic blood pressure and a decrease in pulse pressure due to a reduction in diastolic blood pressure. ${ }^{22}$ This increase in systolic blood pressure combined with obesity may justify the prevalence of ventricular hypertrophy, aortic root dilation, and increased left ventricular mass. ${ }^{5,22-24}$

The practice of physical exercise causes changes at the molecular, functional, and structural levels that contribute to reduced mortality and cardiovascular risk. ${ }^{24,25}$ In coronary patients, its impact translates into increased high-density lipoproteins and decreased triglycerides and blood pressure, improving endothelial function and reducing coronary ischemia and the risk of coronary disease mortality. 25,26

A recent review study systematized the available scientific evidence regarding the cardiovascular benefits of exercise in aging, showing that it contributes to improving cardiovascular function and reverses age-related functional decline. ${ }^{25}$ However, it identifies the need to develop innovative and adapted intervention strategies to optimize cardiovascular benefits in the context of aging.

The aim of the present study was to investigate, using echocardiography, the heart of a population of older adults at the structural and functional levels, as well as the impact caused by an integrated and multidisciplinary intervention model that included the practice of adapted physical exercise program, evaluating the differences between the best and the worst levels of adherence to physical activity.

\section{METHODS}

\section{Study design, sample and ethical aspects}

A non-randomized intervention study of participants included in the AGA@4life cohort study was conducted to evaluate the effect of a multidisciplinary, personalized intervention model on promoting active and healthy aging. This model combines a holistic approach of the older population and the consequent definition of an adapted intervention plan, designed according to the individual needs, implemented by a multidisciplinary and technically qualified team, bringing together several elements, such as cognitive stimulation, adapted physical activity, multidimensional counseling (nutritional, pharmacological, social, and psychological), and promotion of inclusion.

This study aimed to analyze the data obtained in the baseline evaluation of the population studied, in order to identify the cardiac characteristics of older people and the effect of a multidisciplinary intervention program, with particular emphasis on physical activity, in view of identifying potential benefits of this model in the function and structure of the heart of aging adults.

The sample was recruited from a private day care center in the central region of mainland Portugal (Association for the Defense of the Elderly and Children - ADIC, Vilarinho, Portugal), and included participants older than 65 years of both sexes, with no prior history of cerebrovascular or heart disease (obtained by direct information from the participants), and physically autonomous. The age range was 65-92 years old, and the sampling method used was convenience sampling.

The total cohort consisted of 54 participants, 17 of whom were excluded, as described in the diagram in Figure 1. The baseline evaluation included 37 participants (12 men and 25 women) who underwent a multidisciplinary intervention program for 3 months, after which they were reevaluated. Of these 37 participants, 16 were excluded from the analysis, 6 for withdrawing from the study and 10 for not adhering to the intervention program according to the defined inclusion criteria.

Thus, the second evaluation (post-intervention) included 21 participants ( 7 men and 14 women) divided into 2 groups according to the degree of adherence to the physical exercise program: group 1 , with high adherence (> $90 \%$ of sessions); 
and group 2 , with low adherence ( $<20 \%$ of sessions). The division of participants into 2 groups was arbitrary, seeking to define extreme levels of adherence to the physical exercise program to define experimental conditions that would allow the evaluation of the effects of regular exercise (intervention group) vs a context of greater sedentary lifestyle (control group). This definition of physical exercise levels and the constitution of the groups were made in a post hoc analysis of the data on adherence to the intervention program. The individuals with intermediate levels of physical activity were excluded from the analysis. The multidisciplinary intervention was similar in all aging adults, except for the physical exercise component, as previously described.

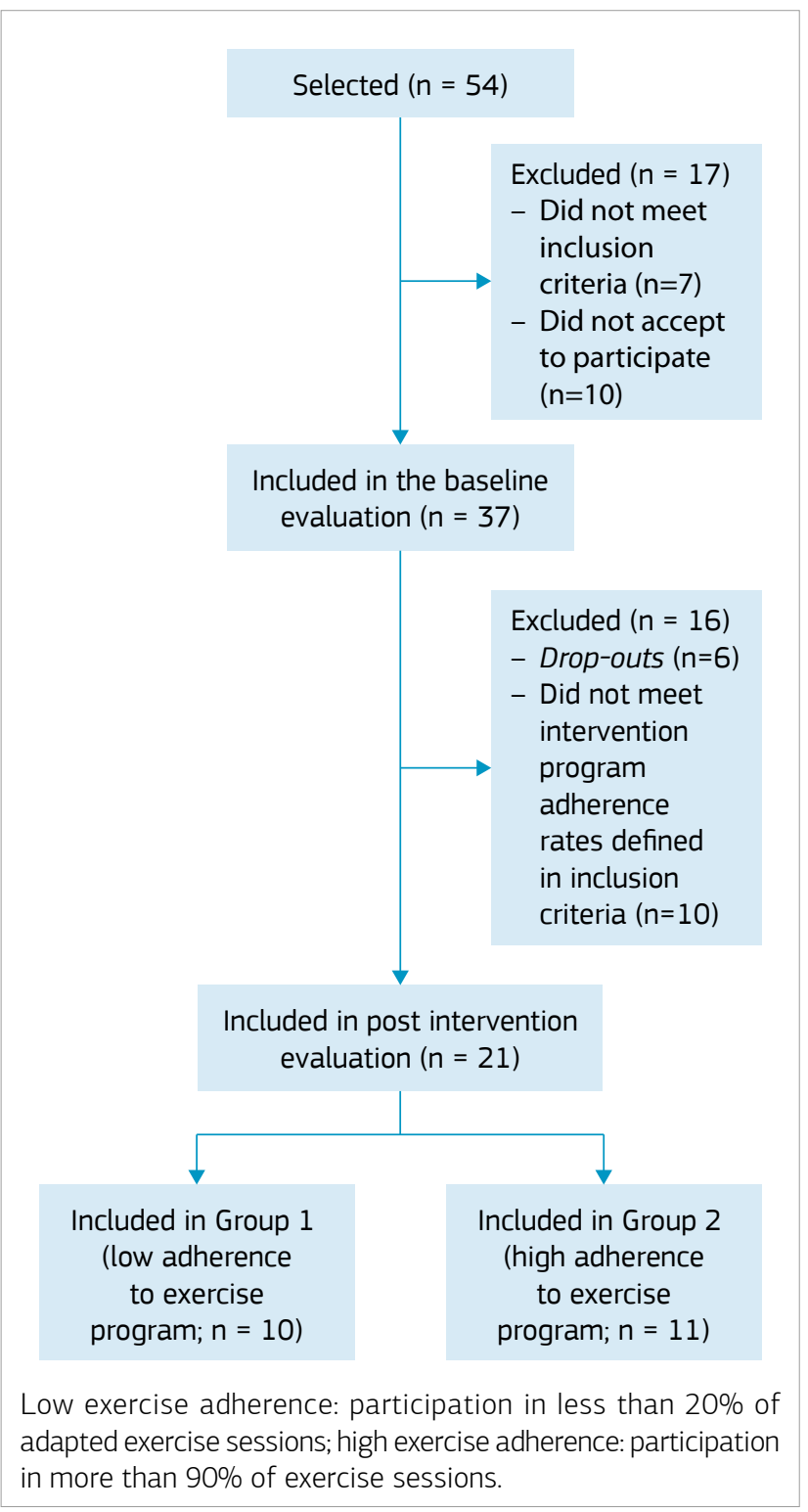

Figure 1 Diagram representing the sample organization in the study steps.
The organization of the sample throughout the study steps is represented in the diagram of Figure 1.

The study complied with the Helsinki Declaration recommendations and was approved by the Research Ethics Committee of the Polytechnic Institute of Coimbra. Anonymity and data confidentiality were guaranteed, the research was strictly scientific, and there was no conflict of interest to declare. All participants provided written informed consent.

\section{General procedure}

The older adults were invited to participate in the study in January 2018. In February and March 2018, a multidisciplinary diagnostic evaluation of each participant was performed, including the collection of demographic and clinical information based on a structured questionnaire designed for this purpose. Information included comorbidities, ongoing medication, nutritional profile, daily activity profile, cardiovascular risk profile, and history of falls. Blood and urine samples were collected for laboratory study, and several diagnostic methodologies for multisystem characterization were implemented, whose results will not be discussed in the present work.

Between the 2 evaluation moments, a 3-month multidisciplinary intervention program was implemented, which included the personalized physical exercise program, besides nutritional adjustment, pharmacological counseling and complementary psychosocial activities.

\section{Echocardiographic evaluation}

Echocardiographic variables were recorded by a General Electric Vivid E echocardiograph with a multifrequency probe by a single and experienced operator.

All examinations were performed according to the recommendations of the American Society of Echocardiography and the European Association of Cardiovascular Imaging. ${ }^{27,28}$ The following ultrasound methods were performed in all subjects: M-mode, Two-dimensional, Doppler, and Tissue Doppler echocardiogram, which determined the cavity diameters, LV wall thickness, aortic root diameter, maximum blood velocities across the aortic, mitral, tricuspid, and pulmonary valves, and the velocity of longitudinal movement of the mitral and tricuspid annulus. Tricuspid annular plane systolic excursion (TAPSE) and heart rate were also measured.

\section{Anthropometry}

Height was assessed in centimeters with the individual standing barefoot in an upright position with the body raised to the fullest extent and the head erect looking forward in the Frankfurt position (lower orbital arch aligned horizontally 
with the ear), with the back and the back of the knees against the measuring instrument, and joined feet. Weight in kilograms and lean and fat mass in percentage were calculated by bioelectrical impedance using the InBody 230 equipment. Body surface area, expressed in square meters, was calculated using the DuBois \& DuBois formula, and body mass index, by the Quetelet index. Waist circumference was determined over the skin, with the individual wearing no clothes in the area to be assessed, with vertical trunk, motionless relaxed abdomen, arms hanging with palms facing inward, erect head, and joined feet.

For practical purposes and to reduce the margin of error, the measurement was performed at the end of the breathing cycle, without the tape measure exerting any compression on the skin but remaining adjusted to it. The calculated value was the mean of the 2 measurements. Waist circumference was measured at exhalation midway between lower rib margin and the iliac crest. Hip perimeter was measured with the individual standing with joined feet at the level of maximum prominence of the buttocks at a horizontal level. Leg circumference was measured around the largest circumference in the space between the ankle and the knee. The value calculated was the mean of 2 measurements.

\section{Blood pressure measurement}

Blood pressure was automatically obtained with the Mobilo-Graph device (EMI, Stolberg, Germany) in participants without any tobacco or caffeine intake in the preceding 2 hours. The measurement was performed at the level of the brachial artery with the participant seated, after a 5-minute rest period, with the arm supported at level of the heart and free from any constrictive effect of clothing. The final value was the mean of 3 consecutive measurements.

\section{Multidisciplinary Intervention}

\section{Physical exercise}

For a more appropriate planning, a scale was designed to group participants according to physical activity levels. The following aspects were considered: the baseline evaluation and the purpose of motivating the aging adults to participate in the proposed activities, participants limitations, promoting the taste for the practice; personal interests; and schedule of availability, trying to create goals by levels.

Thus, on this scale, level 1 corresponded to the participants who did not perform any type of physical activity and showed many limitations on the level of balance, endurance, coordination, and strength. Level 2 corresponded to the participants who practiced some physical activity, although they did not recognize the benefit on maintaining the practice. They also showed many limitations on the level of endurance, coordination, and some limitations on the level of balance and strength. Finally, level 3 corresponded to participants with levels of self-efficacy for exercise above the sample mean. Due to the taste for sports, the intervention plan focused mainly on promoting autonomy and prescribing exercises appropriate to their needs. This rating was not based on any predefined scale; it was adjusted whenever necessary, taking into account the continuous evaluation of progress, which allowed a better planning of the activities to be performed.

The second phase of the intervention was the implementation and consolidation of the contents / exercises. The execution of the training plans was made according to space available, time spent by each participant, activities to be developed, and intrinsic motivation of the participants. Over the course of 3 months, from August to October, all participants had the opportunity to have 3 training plans per week, preferably on alternate days. The training plans were prepared in partnership with the physiotherapy team, seeking to combine the proposed activities and prevent participants' fatigue. We sought training plans to improve aerobic capacity, coordination, balance, and strength.

Each training plan had 15 minutes dedicated to the walk:

- level 1: individual work with support;

- level 2: group walk, distance lower than $2 \mathrm{~km}$;

- level 3: group walk, over $2 \mathrm{~km}$.

At an early stage, on ground level; faster over time and on a steeper terrain. Then, 3 series of balance exercises were performed:

- level 1: walking without support or with only 1 support;

- level 2: walking over a line, with 1 support only and then resume walking;

- level 3: performance of the same exercises as Level 2, but 1 of the sets with eyes closed.

After walking, strength exercises were proposed mainly involving the lower limbs, in 3 series:

- level 1: lift the chair with or without support;

- level 2: 10 isometric squats;

- level 3: 20 isometric squats.

To promote upper limb strength, 2 sets of arm rotation, adduction, and abduction without additional load were performed by all participants included in the exercise plan.

Over time, the order of the exercises changed to promote new stimuli and maintain motivation for the practice. The exercises remained the same, promoting memorization 
by participants to enable them to practice autonomously. During this phase, some participants progressed on the scale and others, due to falls or illness, eventually dropped out of the study or regressed on the scale.

The third phase of the intervention was the final evaluation together with the entire intervention team and the participants.

\section{Nutritional and Pharmacological Counseling}

Another intervention component was nutritional counseling, focused on 4 phases: identification of nutritional risk; nutritional assessment (anthropometric assessment); assessment of food intake (questionnaire and 24-hour food diary); biochemical evaluation; and, finally, the intervention component itself, which consisted of the nutritional adjustment of the individual and personalized eating plan.

The pharmacological intervention resulted in the application of 2 questionnaires: one to assess adherence to therapy and another to assess the complexity of the pharmacotherapy regimen.

\section{Statistical analysis}

The data obtained were computerized and compiled in a database built in Excel 2016 (Microsoft Office, Redmond,WA, United States) and then imported and statistically analyzed in the SPSS version 24 (IBM, Armonk, NY, United States).

Categorical variables were reported as frequency and percentages, and the $\chi^{2}$ or the Fisher's exact tests were used when appropriate. The Shapiro-Wilk test was used to confirm the normal distribution of all continuous variables, which were presented as mean and standard deviation (SD). Variables with a non-normal distribution were transformed by the logarithm base 10 .

Student's $t$-test was used for group comparisons for continuous variables in the first assessment. Individual variables were checked for homogeneity of variance by the Levene's test. A 2-factor mixed ANOVA was used to assess changes in variables between the first and second assessments in each group and between groups. The Greenhouse-Geisser correction was applied when sphericity was violated, and Bonferroni's adjustment for degrees of freedom was adopted in multiple comparisons to locate the significant effects of a factor. The comparison between groups in the second assessment was based on an additional analysis of variance (ANCOVA), adjusting the comparison to baseline values (covariate in the model).

Statistical significance was established at a $p<0.05$ for the $95 \%$ confidence interval. The magnitude of the effects was evaluated by the value of $\eta^{2}$.

\section{RESULTS}

After analysis of the standardized questionnaire, 16.2\% $(n=6)$ of the individuals had family history of cardiovascular disease, 24.3\% ( $\mathrm{n}=9)$ were diabetic patients and 54.1\% $(\mathrm{n}=20)$ suffered of dyslipidemia. Since this is a very old population, echocardiography showed concordant structural and functional changes. Thus, $89.2 \%(\mathrm{n}=33)$ of the individuals had fibrosis and $51.2 \%(\mathrm{n}=19)$ aortic valve regurgitation, $73 \%(n=27)$ fibrosis, $68 \%(n=25)$ mitral valve regurgitation, and $29.7 \%(\mathrm{n}=11)$ had tricuspid valve regurgitation (4 with pulmonary artery systolic pressure greater than $35 \mathrm{mmHg}$ ). The pulmonary valve showed no significant changes. Other less frequent changes were also found, such as changed LV segmental contractility, interventricular septum (IVS) basal segment hypertrophy, mitral valve annulus fibrocalcification, and ascending aorta dilation.

The general characteristics of the study sample are presented in Table 1 . We can verify that the total sample has mean age of 82.4 years, mean weight of $65.6 \mathrm{~kg}$, mean height of $152.6 \mathrm{~cm}$, mean body surface of $1.6 \mathrm{~m}^{2}$, and mean body mass index of $28.3 \mathrm{~g} / \mathrm{m}^{2}$. The remaining mean values measured were $101.8 \mathrm{~cm}$ for abdominal circumference, $21.4 \%$ for lean mass, and $25.9 \%$ for fat mass. The mean heart rate was $68 \mathrm{bpm}$, and the systolic blood pressure and mean diastolic pressure were 149.5 and $78.6 \mathrm{mmHg}$, respectively. It was also found that $5.4 \%(\mathrm{n}=2)$ of the individuals had optimal blood pressure, $16.7 \%(\mathrm{n}=6)$ normal blood pressure, $32.4 \%$ $(\mathrm{n}=12)$ high normal blood pressure, and $45.8 \%(\mathrm{n}=17)$, hypertension.

Table 2 shows the structural echocardiographic variables measured by $\mathrm{M}$-mode and two-dimensional echocardiography for men and women and for the total sample under study. The mean values found for the LV end-systolic and end-diastolic diameters for the entire sample were 35.1 and $54.2 \mathrm{~mm}$; for the mean posterior wall thickness and for IVS at end-diastole, 7.4 and $7.5 \mathrm{~mm}$; and for the mean LV shortening fraction, $35.1 \%$. The mean value of left ventricular diastolic mass adjusted by body surface area was $89.7 \mathrm{~g} / \mathrm{m}^{2}$, and relative wall thickness was 0.3 .

The mean dimensions of the aortic root and left atrium calculated by M-mode were 31.0 and $37.4 \mathrm{~mm}$, respectively, while the mean areas of the right and left atria measured by 2-dimensional echocardiography were 11.8 and $14.2 \mathrm{~cm}^{2}$. The mean TAPSE value was $19.8 \mathrm{~mm}$.

Table 3 shows maximum transvalvular flow velocity as determined by Doppler and maximum velocity of the LV longitudinal movement as determined by tissue Doppler for men and women and for the total sample. The mean values of maximum velocity of the $\mathrm{E}$ - and A-waves and the 
$\mathrm{E} / \mathrm{A}$ ratio of the mitral valve were $51.8 \mathrm{~cm} / \mathrm{s}, 78.5 \mathrm{~cm} / \mathrm{s}$, and $0.7 \mathrm{~cm} / \mathrm{s}$, respectively, while the maximum velocities of the $\mathrm{E}$ - and A-waves of the tricuspid valve were 38.5 and $45.8 \mathrm{~cm} / \mathrm{s}$. The mean values of the maximum velocities of transaortic and transpulmonary flow were 1.3 and $0.8 \mathrm{~m} / \mathrm{s}$. The mean values of the maximum velocities of the E', A' and S' waves of the septal mitral valve annulus were, respectively, $5.1,8.3$ and $6.4 \mathrm{~cm} / \mathrm{s}$ and of the lateral annulus, $6.7,9.5$, and $7,5 \mathrm{~cm} / \mathrm{s}$, respectively. The mean of the E/E' ratio of the septal mitral annulus was 10.2, and the mean of the E/E' ratio of the lateral mitral annulus, 8.7. Tissue Doppler evaluation of tricuspid valve annulus showed mean values for the maximum velocities of the E', A' and S' waves of, respectively, $7.2,12.4$, and $10.9 \mathrm{~cm} / \mathrm{s}$. The mean of the $\mathrm{E} / \mathrm{E}$ ' ratio of the tricuspid annulus was 5.8 .

\section{Second evaluation}

The second evaluation focused on 21 individuals from the first evaluation, selected according to their adherence to the physical intervention program:

- group 1: low adherence (<20\% of sessions);

- group 2: high adherence ( $>90 \%$ of sessions).

Group 1 consisted of 10 participants and group 2 of 11 participants. The groups did not differ significantly in the comparison of their baseline, clinical, and sociodemographic characteristics. The methodology followed for data collection was superimposed on that of the first evaluation.

Table 1 Anthropometric variables, heart rate, and blood pressure.

\begin{tabular}{l|c|c|c}
\hline & $\begin{array}{c}\text { Women } \\
(\mathrm{n}=25) \\
\text { Mean } \pm \text { SD }\end{array}$ & $\begin{array}{c}\text { Men } \\
(\mathrm{n}=12) \\
\text { Mean } \pm \text { SD }\end{array}$ & $\begin{array}{c}\text { Total } \\
(\mathrm{n}=37) \\
\text { Mean } \pm \text { SD }\end{array}$ \\
\hline Age (years) & $83.6 \pm 7.2$ & $79.2 \pm 8.7$ & $82.4 \pm 7.7$ \\
\hline Weight $(\mathrm{kg})$ & $63.5 \pm 10.7$ & $72.1 \pm 12.2$ & $65.6 \pm 11.5$ \\
\hline Height $(\mathrm{cm})$ & $148.9 \pm 6.4$ & $164.5 \pm 7.3$ & $152.6 \pm 9.3$ \\
\hline BS $\left(\mathrm{m}^{2}\right)$ & $1.6 \pm 0.2$ & $1.8 \pm 0.2$ & $1.6 \pm 0.2$ \\
\hline BMI $\left(\mathrm{kg} / \mathrm{m}^{2}\right)$ & $28.8 \pm 4.3$ & $26.9 \pm 3.4$ & $28.3 \pm 4.1$ \\
\hline WC $(\mathrm{cm})$ & $102.3 \pm 8.6$ & $100.4 \pm 10.1$ & $101.8 \pm 8.9$ \\
\hline LM $(\%)$ & $18.9 \pm 2.9$ & $28.1 \pm 3.2$ & $21.4 \pm 5.1$ \\
\hline FM $(\%)$ & $27.4 \pm 8.3$ & $21.8 \pm 8.7$ & $25.9 \pm 8.6$ \\
\hline HR $(\mathrm{bpm})$ & $64.7 \pm 12.6$ & $69.1 \pm 10.9$ & $68.1 \pm 11.3$ \\
\hline SBP $(\mathrm{mmHg})$ & $148.6 \pm 32.1$ & $152.4 \pm 25.7$ & $149.5 \pm 30.3$ \\
\hline DPB $(\mathrm{mmHg})$ & $79.7 \pm 15.3$ & $75.4 \pm 14.8$ & $78.6 \pm 15.1$ \\
\hline
\end{tabular}

BS: body surface; BMI: body mass index; WC: waist circumference; MM: lean mass; FM: fat mass; HR: heart rate; SBP: systolic blood pressure; DBP: diastolic blood pressure; SD: standard deviation.
Table 4 shows the structural echocardiographic variables calculated by M-mode and 2-dimensional echocardiography for men and women, and for the total sample under study. The mean LV end-systolic and end-diastolic diameters were 35.8 and $54.4 \mathrm{~mm}$, respectively; the mean $L V$ end-diastolic posterior wall thickness and IVS thickness was $7.3 \mathrm{~mm}$; and the $\mathrm{LV}$ shortening fraction, $34.1 \%$. The mean values of the aorta root and the left atrium by M-mode were, respectively, 31.2 and 38,2 $\mathrm{mm}$. The mean left ventricular mass corrected for the body surface was $88.2 \mathrm{~g} / \mathrm{m}^{2}$ and the mean relative wall thickness, $0.3 \mathrm{U}$.The mean right atrial area was $12.1 \mathrm{~cm}^{2}$, and the left atrium, $14.4 \mathrm{~cm}^{2}$. The tricuspid annular plane systolic excursion was $20.4 \mathrm{~mm}$.

Table 5 shows the maximum velocities of transvalvular flows calculated by Doppler and the maximum velocities of LV longitudinal movement calculated by tissue Doppler for men and women and for the total study sample. The mean values of the maximum velocity of the $\mathrm{E}$ - and $\mathrm{A}$-waves of the mitral valve were 54.3 and $80.1 \mathrm{~cm} / \mathrm{s}$ and the $\mathrm{E} / \mathrm{A}$ ratio $0.8 \mathrm{U}$, while the mean maximum velocities of the $\mathrm{E}$ and $\mathrm{A}$ wave of the tricuspid valve was 40.7 and $48.1 \mathrm{~cm} / \mathrm{s}$, respectively. The average maximum transaortic and transpulmonary flow velocities were 1.3 and $0.8 \mathrm{~m} / \mathrm{s}$.

Table 2 Structural echocardiographic variables.

\begin{tabular}{l|c|c|c} 
& $\begin{array}{c}\text { Women } \\
(\mathrm{n}=25) \\
\text { Mean } \pm \text { SD }\end{array}$ & $\begin{array}{c}\text { Men } \\
(\mathrm{n}=12) \\
\text { Mean } \pm \text { SD }\end{array}$ & $\begin{array}{c}\text { Total } \\
(\mathrm{n}=37) \\
\text { Mean } \pm \text { SD }\end{array}$ \\
LVSD $(\mathrm{mm})$ & $33.9 \pm 3.9$ & $38.6 \pm 4.1$ & $35.1 \pm 4.3$ \\
\hline LVDD $(\mathrm{mm})$ & $52.6 \pm 5.0$ & $59.2 \pm 3.5$ & $54.2 \pm 5.4$ \\
\hline LVPWd $(\mathrm{mm})$ & $7.3 \pm 0.4$ & $7.7 \pm 0.5$ & $7.4 \pm 0.4$ \\
\hline IVSd $(\mathrm{mm})$ & $7.4 \pm 0.6$ & $7.7 \pm 0.6$ & $7.5 \pm 0.6$ \\
\hline ARD $(\mathrm{mm})$ & $29.7 \pm 2.7$ & $34.9 \pm 3.7$ & $31.0 \pm 3.7$ \\
\hline LAD $(\mathrm{mm})$ & $37.0 \pm 5.6$ & $37.0 \pm 5.6$ & $37.4 \pm 5.7$ \\
\hline F. Sh $(\%)$ & $34.8 \pm 4.5$ & $35.3 \pm 4.3$ & $35.1 \pm 4.3$ \\
\hline A_AD $\left(\mathrm{cm}{ }^{2}\right)$ & $11.8 \pm 2.5$ & $11.9 \pm 3.7$ & $11.8 \pm 3.4$ \\
\hline RA_A $\left(\mathrm{cm}^{2}\right)$ & $14.6 \pm 5.3$ & $12.9 \pm 2.8$ & $14.2 \pm 4.8$ \\
\hline LVRWT & $0.3 \pm 0.03$ & $0.3 \pm 0.02$ & $0.3 \pm 0.03$ \\
\hline LVMd $(\mathrm{g})$ & $136.1 \pm 26.9$ & $177.78 \pm 28.9$ & $146.2 \pm 32.5$ \\
\hline LVMI $\left(\mathrm{g} / \mathrm{m}^{2}\right)$ & $86.5 \pm 15.1$ & $99.7 \pm 12.9$ & $89.7 \pm 15.5$ \\
\hline TAPSE $(\mathrm{mm})$ & $19.5 \pm 2.4$ & $20.7 \pm 2.8$ & $19.8 \pm 2.6$ \\
\hline LVSD:left & & &
\end{tabular}

LVSD: left ventricular systolic diameter; LVDD: left ventricular diastolic diameter; LVPWd: left ventricular posterior wall end-diastolic thickness; IVSd: interventricular septum end-diastolic thickness; ARD: aortic root diameter; LAD: left atrial diameter; F. Sh: left ventricular shortening fraction; RA_A: right atrium area; LA_A: left atrium area; LVRWT: left ventricular relative wall thickness; LVMd: left ventricular mass in diastole; LVMI: left ventricular mass index; TAPSE: tricuspid annular plane systolic excursion; SD: standard deviation. 
Regarding the maximum velocities of the E', A', and S' waves of the septal mitral valve annulus, mean values were $5.8,8.4$, and $7.0 \mathrm{~cm} / \mathrm{s}$, respectively, while for the lateral annulus, maximum velocities of the E', A', and S' waves were of $6.4,9.6$, and $8.0 \mathrm{~cm} / \mathrm{s}$. For the mitral septal and lateral $\mathrm{E} / \mathrm{E}$ ' ratio, the mean values were respectively 9.8

Table 3 Maximum velocities determined by conventional Doppler and by Tissue Doppler.

\begin{tabular}{|c|c|c|c|}
\hline & $\begin{array}{c}\text { Women } \\
(n=25) \\
\text { Mean } \pm \text { SD }\end{array}$ & $\begin{array}{c}\text { Men } \\
(n=12) \\
\text { Mean } \pm \text { SD }\end{array}$ & $\begin{array}{c}\text { Total } \\
(n=37) \\
\text { Mean } \pm \text { SD }\end{array}$ \\
\hline Mitral E (cm/s) & $56.6 \pm 26.8$ & $46.1 \pm 17.2$ & $51.8 \pm 24.8$ \\
\hline Mitral A (cm/s) & $77.7 \pm 21.5$ & $81.2 \pm 15.7$ & $78.5 \pm 20.1$ \\
\hline Mitral E/A & $0.8 \pm 0.7$ & $0.6 \pm 0.2$ & $0.7 \pm 0.6$ \\
\hline Tricuspid E (cm/s) & $38.7 \pm 9.5$ & $38.1 \pm 9.7$ & $38.5 \pm 9.4$ \\
\hline Tricuspid A (cm/s) & $48.0 \pm 14.2$ & $39.0 \pm 12.1$ & $45.8 \pm 14.1$ \\
\hline TFR (m/s) & $1.3 \pm 0.3$ & $1.3 \pm 0.4$ & $1.3 \pm 0.3$ \\
\hline TFV (m/s) & $0.8 \pm 0.2$ & $0.8 \pm 0.2$ & $0.8 \pm 0.2$ \\
\hline $\begin{array}{l}\text { Septal } \\
\text { mitral E' (cm/s) }\end{array}$ & $5.0 \pm 1.3$ & $5.1 \pm 0.8$ & $5.1 \pm 1.2$ \\
\hline $\begin{array}{l}\text { Septal } \\
\text { mitral A' (cm/s) }\end{array}$ & $8.1 \pm 2.1$ & $8.8 \pm 1.8$ & $8.3 \pm 2.0$ \\
\hline $\begin{array}{l}\text { Septal } \\
\text { mitral S' (cm/s) }\end{array}$ & $6.2 \pm 1.2$ & $7.1 \pm 1.8$ & $6.4 \pm 1.4$ \\
\hline Septal mitral E/E' & $10.6 \pm 3.7$ & $9.0 \pm 2.8$ & $10.2 \pm 3.6$ \\
\hline $\begin{array}{l}\text { Lateral } \\
\text { mitral E' }(\mathrm{cm} / \mathrm{s})\end{array}$ & $6.1 \pm 2.4$ & $8.2 \pm 3.9$ & $6.7 \pm 2.9$ \\
\hline $\begin{array}{l}\text { Lateral } \\
\text { mitral A' }(\mathrm{cm} / \mathrm{s})\end{array}$ & $9.6 \pm 3.1$ & $9.3 \pm 3.5$ & $9.5 \pm 3.1$ \\
\hline $\begin{array}{l}\text { Lateral } \\
\text { mitral S' (cm/s) }\end{array}$ & $7.4 \pm 1.5$ & $8.0 \pm 2.7$ & $7.5 \pm 1.8$ \\
\hline Lateral mitral E/E' & $9.3 \pm 4.8$ & $6.8 \pm 3.6$ & $8.7 \pm 4.6$ \\
\hline Tricuspid E' (cm/s) & $7.1 \pm 2.8$ & $7.6 \pm 2.5$ & $7.2 \pm 2.7$ \\
\hline Tricuspid A' (cm/s) & $12.4 \pm 2.9$ & $12.3 \pm 3.7$ & $12.4 \pm 3.1$ \\
\hline Tricuspid S' (cm/s) & $11.0 \pm 2.8$ & $10.4 \pm 2.9$ & $10.9 \pm 2.8$ \\
\hline Tricuspid E/E' & $5.9 \pm 2.0$ & $5.4 \pm 1.7$ & $5.8 \pm 1.9$ \\
\hline
\end{tabular}

Mitral E: mitral E wave velocity; Mitral A': mitral A wave velocity; Tricuspid E: tricuspid E wave velocity; Tricuspid A: tricuspid A wave velocity; TFR: transaortic flow rate; TFV: transpulmonary flow velocity; Septal Mitral E': septal E' velocity; Septal mitral A': septal mitral A' wave velocity; Septal Mitral S: septal mitral S' wave velocity; Lateral Mitral E': lateral mitral E' wave velocity; Lateral mitral A': lateral mitral A' wave velocity; lateral mitral S': lateral mitral S' velocity; Tricuspid E': tricuspid E' wave velocity; Tricuspid A: tricuspid A' wave velocity; tricuspid S': tricuspid S' wave velocity; SD: standard deviation and 8.9 U. For the tricuspid valve, the mean values found for the maximum velocities of the E', A', and S' waves were $8.0,11.2$, and $10,9 \mathrm{~cm} / \mathrm{s}$, respectively, and for the E/E' ratio, 5.6 U.

\section{Correlation between the 2 evaluation moments} and the groups with and without physical activity

Table 6 shows only the significant correlations between the 2 evaluation moments, as well as between the groups with physical exercise and without physical exercise.

As it can be seen in Table 6, most of the statistically significant changes were found in the group that performed personalized exercise (Group 2). In this group, between the first and second evaluation, there were statistically significant changes, with higher values in the second evaluation, for the maximum velocities of the E' waves of the septal annulus ( $p=0.016)$, the S' of the mitral valve lateral annulus $(p=0.02)$, and the E' wave of the tricuspid valve $(p=0.027)$. The values were statistically significant, but lower in the second evaluation for $\mathrm{LV}$ relative wall thickness $(\mathrm{p}=0.033)$. In the second evaluation, the LV end-diastolic

Table 4 Structural echocardiographic variables.

\begin{tabular}{l|c|c|c} 
& $\begin{array}{c}\text { Women } \\
(\mathrm{n}=14) \\
\text { Mean } \pm \text { SD }\end{array}$ & $\begin{array}{c}\text { Men } \\
(\mathrm{n}=7) \\
\text { Mean } \pm \text { SD }\end{array}$ & $\begin{array}{c}\text { Total } \\
(\mathrm{n}=21) \\
\text { Mean } \pm \text { SD }\end{array}$ \\
\hline LVSD $(\mathrm{mm})$ & $34.1 \pm 3.4$ & $39.3 \pm 3.7$ & $35.8 \pm 4.2$ \\
\hline LVDD $(\mathrm{mm})$ & $51.7 \pm 4.4$ & $59.7 \pm 4.2$ & $54.4 \pm 5.7$ \\
\hline LVPWd $(\mathrm{mm})$ & $7.2 \pm 0.1$ & $7.6 \pm 0.5$ & $7.3 \pm 0.4$ \\
\hline IVSd $(\mathrm{mm})$ & $7.2 \pm 0.4$ & $4.6 \pm 0.5$ & $7.3 \pm 0.4$ \\
\hline ARD $(\mathrm{mm})$ & $29.1 \pm 2.9$ & $35.4 \pm 2.9$ & $31.2 \pm 4.2$ \\
\hline LAD $(\mathrm{mm})$ & $37.4 \pm 5.7$ & $39.6 \pm 7.1$ & $38.2 \pm 6.1$ \\
\hline F. Sh $(\%)$ & $34.1 \pm 2.4$ & $34.1 \pm 2.1$ & $34.1 \pm 2.2$ \\
\hline A_AD $\left(\mathrm{cm}{ }^{2}\right)$ & $12.1 \pm 3.6$ & $12.1 \pm 2.4$ & $12.1 \pm 3.2$ \\
\hline RA_A $\left(\mathrm{cm}^{2}\right)$ & $15.1 \pm 5.7$ & $13.1 \pm 2.7$ & $14.4 \pm 4.9$ \\
\hline LVRWT & $0.3 \pm 0.02$ & $0.3 \pm 0.02$ & $0.3 \pm 0.02$ \\
\hline LVMd $(\mathrm{g})$ & $126.1 \pm 20.4$ & $177.4 \pm 32.17$ & $143.2 \pm 34.6$ \\
\hline LVMI $\left(\mathrm{g} / \mathrm{m}^{2}\right)$ & $82.8 \pm 12.6$ & $99.0 \pm 15.8$ & $88.2 \pm 15.5$ \\
\hline TAPSE $(\mathrm{mm})$ & $20.4 \pm 1.5$ & $20.3 \pm 2.0$ & $20.4 \pm 1.6$ \\
\hline
\end{tabular}

LVSD: left ventricular systolic diameter; LVDD: left ventricular diastolic diameter; LVPWd: left ventricular posterior wall end-diastolic thickness; IVSd: interventricular septum end-diastolic thickness; ARD: aortic root diameter; LAD: left atrial diameter; F. Sh: left ventricular shortening fraction; RA_A: right atrium area; LA_A: left atrium area; LVRWT: left ventricular relative wall thickness; LVMd: left ventricular mass in diastole; LVMI: left ventricular mass index; TAPSE: tricuspid annular plane systolic excursion; SD: standard deviation. 
diameter was lower in the group practicing personalized exercise $(\mathrm{p}=0.041)$.

Regarding the group that did not perform adapted exercise (Group 1), there were statistically significant changes only for the maximum velocity of the A' wave of the tricuspid valve $(p=0.022)$, with lower values in the second evaluation.

Table 5 Maximum velocities determined by conventional Doppler and by Tissue Doppler.

\begin{tabular}{|c|c|c|c|}
\hline & $\begin{array}{c}\text { Women } \\
(n=14) \\
\text { Mean } \pm \text { SD }\end{array}$ & $\begin{array}{c}\text { Men } \\
(n=7) \\
\text { Mean } \pm \text { SD }\end{array}$ & $\begin{array}{c}\text { Total } \\
(n=21) \\
\text { Mean } \pm \text { SD }\end{array}$ \\
\hline Mitral E (cm/s) & $53.5 \pm 20.7$ & $55.9 \pm 13.1$ & $54.3 \pm 18.2$ \\
\hline Mitral A (cm/s) & $76.8 \pm 25.1$ & $83.6 \pm 17.5$ & $80.1 \pm 22.9$ \\
\hline Mitral E/A & $0.8 \pm 0.7$ & $0.7 \pm 0.3$ & $0.8 \pm 0.6$ \\
\hline Tricuspid E (cm/s) & $42.6 \pm 12.4$ & $37.0 \pm 6.0$ & $40.7 \pm 10.8$ \\
\hline Tricuspid A (cm/s) & $50.8 \pm 16.6$ & $42.7 \pm 14.6$ & $48.1 \pm 16.1$ \\
\hline TFR (m/s) & $1.3 \pm 0.2$ & $1.4 \pm 0.4$ & $1.3 \pm 0.3$ \\
\hline TFV (m/s) & $0.8 \pm 0.2$ & $0.8 \pm 0.2$ & $0.8 \pm 0.2$ \\
\hline $\begin{array}{l}\text { Septal } \\
\text { mitral E' (cm/s) }\end{array}$ & $5.6 \pm 1.2$ & $6.0 \pm 1.3$ & $5.8 \pm 1.2$ \\
\hline $\begin{array}{l}\text { Septal } \\
\text { mitral A' (cm/s) }\end{array}$ & $8.1 \pm 1.8$ & $9.0 \pm 1.8$ & $8.4 \pm 1.8$ \\
\hline $\begin{array}{l}\text { Septal } \\
\text { mitral S' (cm/s) }\end{array}$ & $6.6 \pm 1.6$ & $7.9 \pm 2.1$ & $7.0 \pm 1.8$ \\
\hline Septal mitral E/E' & $9.7 \pm 3.7$ & $9.8 \pm 3.5$ & $9.8 \pm 3.5$ \\
\hline $\begin{array}{l}\text { Lateral } \\
\text { mitral E' (cm/s) }\end{array}$ & $6.3 \pm 1.9$ & $6.7 \pm 2.4$ & $6.4 \pm 2.0$ \\
\hline $\begin{array}{l}\text { Lateral } \\
\text { mitral A' (cm/s) }\end{array}$ & $10.0 \pm 2.4$ & $8.9 \pm 3.7$ & $9.6 \pm 2.8$ \\
\hline $\begin{array}{l}\text { Lateral } \\
\text { mitral S’ (cm/s) }\end{array}$ & $7.6 \pm 1.8$ & $8.9 \pm 3.6$ & $8.0 \pm 2.5$ \\
\hline Lateral mitral E/E' & $8.7 \pm 2.8$ & $9.4 \pm 4.3$ & $8.9 \pm 3.3$ \\
\hline Tricuspid E' (cm/s) & $7.7 \pm 3.0$ & $8.4 \pm 3.6$ & $8.0 \pm 3.1$ \\
\hline Tricuspid A' (cm/s) & $11.4 \pm 3.0$ & $10.9 \pm 1.3$ & $11.2 \pm 2.5$ \\
\hline Tricuspid S' (cm/s) & $10.5 \pm 2.4$ & $11.1 \pm 2.5$ & $10.9 \pm 2.4$ \\
\hline Tricuspid E/E' & $6.0 \pm 2.2$ & $5.0 \pm 1.7$ & $5.6 \pm 2.1$ \\
\hline
\end{tabular}

Mitral E: mitral E wave velocity; A mitral: mitral E wave velocity; E tricuspid: tricuspid E wave velocity; tricuspid A: tricuspid $E$ wave velocity; TFR: transaortic flow rate; TFV: transpulmonary flow velocity; Septal Mitral E': septal E' velocity; Septal mitral A': septal mitral A' wave velocity; Septal Mitral S: septal mitral S' wave velocity; Lateral Mitral E': lateral mitral E' wave velocity; Lateral mitral A': lateral mitral A' velocity; lateral mitral S': lateral mitral S' wave velocity; Tricuspid E': tricuspid E' wave velocity; Tricuspid A: tricuspid A' wave velocity; tricuspid S': tricuspid S' wave velocity; SD: standard deviation.
In relation to TAPSE, statistically significant changes were found both in the group that performed adapted exercise $(p=0.004)$ and in the group that did not $(p=0.045)$, with higher values in the second evaluation.

\section{DISCUSSION}

The main objective of the study was to identify, using echocardiography, the cardiac characteristics of a population of older adults and to evaluate the changes possibly induced by a multidisciplinary intervention program, with special focus on the component of adapted physical exercise.

Regarding the structural changes found, there was a decrease in the LV end-diastolic diameter in the individuals submitted to exercise. Although Guirado et al..$^{29}$ obtained similar results, Galetta et al..$^{30}$ pointed to an increase in the end-diastolic diameter, and Jungblut et $\mathrm{al}^{31}{ }^{31}$, in an investigation conducted in 12 athletes aged $65-75$ years and 12 sedentary older adults aged $65-73$ years, as well as Nottin et al. ${ }^{32}$, did not find significant differences for this parameter. Regarding the LV wall thickness, no statistically significant differences were found between the 2 evaluation moments. Suboc et al. ${ }^{33}$ obtained similar results in a study with 114 sedentary older adults aged $50-80$ years, participating in an exercise program for 12 weeks. However, Guirado et al. ${ }^{29}$ observed an increase in thickness, and Nottin et al..$^{32}$ did not perceive statistically significant differences for this parameter.

Left ventricular mass indexed to the body surface increased both in the group that participated in the exercise program $\left(2.538 \mathrm{~g} / \mathrm{m}^{2}\right)$ and in the group that did not participate $\left(2.625 \mathrm{~g} / \mathrm{m}^{2}\right)$, but this variation was not statistically significant. Similar results were seen by other authors. ${ }^{34-41}$ On the other hand, Guirado et al., ${ }^{29}$ also after implementation of an intervention program with physical exercise, indicated the existence of a decrease in left ventricular mass, and Nottin et al..$^{32}$ did not find statistically significant differences before and after executing an intervention plan. Haykowsky et al., ${ }^{36}$ in a study of 35 women aged 60-78 years who underwent different types of exercise for 12 weeks, reported no statistically significant changes in LV dimensions, for wall thickness and left ventricular mass. LVRWT in our study was lower than 0.45 , which translates into eccentric remodeling. Similar results were obtained by Fujimoto et al. ${ }^{34}$

Regarding the studied functional variables, statistically significant changes were found in the group that performed adapted physical exercise, in the maximum velocities of the E' wave of the septal annulus and the S' wave of the mitral valve lateral annulus, as well as in the maximum velocity of the $\mathrm{E}^{\prime}$ wave of the tricuspid valve. Our results were in agreement 
with those of Fujimoto et al. ${ }^{34}$ in a study with 24 aging adults, including 12 sedentary adults $(69.3 \pm 3$ years $)$ and 12 athletes $(67.8 \pm 3$ years), in which a training program was executed with the latter. However, Galetta et al., ${ }^{30}$ in a study of 25 healthy individuals ( $67.6 \pm 4.5$ years) and 25 athletes (68.1 \pm 6.2 years) and Nottin et al..$^{32}$, in a study with 3 groups of men (14 older adults, 15 sedentary adults, and 14 older adults with training habits), did not find statistically significant differences between groups for the maximum velocity of the S' wave, both in the septal and lateral annulus.

Although without statistical significance, our study found a reduction in the $\mathrm{E}$ 'wave of the mitral valve lateral annulus in both groups, as well as an increase in the E/A ratio in the group experiencing adapted exercise. Gates et al. ${ }^{37}$ studied by echocardiography 160 men subdivided into 3 groups according to age group (young, adult, and older adults) and concluded that the $\mathrm{E} / \mathrm{A}$ ratio tends to decrease with age, and its relationship with the level of exercise practiced is insignificant. Guirado et al. ${ }^{29}$,in a study conducted in 16 individuals with controlled hypertension and aged 60-85 years, also verified this fact, however they observed that intense and prolonged training seems to preserve diastolic dysfunction during aging. This was also observed by Prasad et al., ${ }^{38}$ in a study of 30 healthy sedentary older adults ( $70 \pm 4$ years), 12 active older adults ( $68 \pm 3$ years), and 12 healthy sedentary youth ( $32 \pm 9$ years), in which it was found that lifelong exercise can preserve cardiac function.

Table 6 Intra- and intergroup variations in echocardiographic parameters with significant variations from baseline to post-intervention.

\begin{tabular}{|c|c|c|c|c|c|}
\hline & & Total $(n=21)$ & Group $1 \quad(n=10)$ & Group $2(n=11)$ & $p$ \\
\hline \multirow{4}{*}{$\begin{array}{l}\text { Maximum velocity of the } \\
\text { E' wave of the septal } \\
\text { annulus (cm/s) }\end{array}$} & $1^{\text {st }}$ assessment & $5.0 \pm 1.2$ & $5.5 \pm 1.5$ & $4.6 \pm 0.9$ & 0.163 \\
\hline & $2^{\text {nd }}$ assessment & $5.8 \pm 1.2$ & $6.0 \pm 0.5$ & $5.6 \pm 1.5$ & 0.991 \\
\hline & Difference & 0.810 & 0.500 & 1.000 & \\
\hline & $p$ (ANOVA) & 0.009 & 0.463 & 0.016 & \\
\hline \multirow{4}{*}{$\begin{array}{l}\text { Maximum velocity of the } \\
\text { S' wave of mitral lateral } \\
\text { annulus (cm/s) }\end{array}$} & $1^{\text {st }}$ assessment & $7.6 \pm 2.0$ & $8.4 \pm 1.1$ & $7.2 \pm 2.3$ & 0.121 \\
\hline & $2^{\text {nd }}$ assessment & $8.0 \pm 2.5$ & $8.0 \pm 2.7$ & $8.0 \pm 2.6$ & 0.186 \\
\hline & Difference & 0.381 & -0.375 & 0.846 & \\
\hline & $p$ (ANOVA) & 0.351 & 0.685 & 0.05 & \\
\hline \multirow{4}{*}{$\begin{array}{l}\text { Tricuspid annulus maximum } \\
\text { velocity of } E^{\prime}(\mathrm{cm} / \mathrm{s})\end{array}$} & $1^{\text {st }}$ assessment & $7.1 \pm 3.04$ & $8.6 \pm 4.3$ & $6.2 \pm 1.5$ & 0.165 \\
\hline & $2^{\text {nd }}$ assessment & $8.0 \pm 3.1$ & $9.4 \pm 4.5$ & $7.1 \pm 1.6$ & 0.811 \\
\hline & Difference & 0.810 & 0.750 & 0.846 & \\
\hline & $p$ (ANOVA) & 0.034 & 0.378 & 0.027 & \\
\hline \multirow{4}{*}{$\begin{array}{l}\text { Tricuspid valve } \\
\text { maximum velocity of } \\
\text { the } A-\text { wave }(\mathrm{cm} / \mathrm{s})\end{array}$} & $1^{\text {st }}$ assessment & $47.0 \pm 14.5$ & $52.5 \pm 10.2$ & $43.6 \pm 16.0$ & 0.137 \\
\hline & $2^{\text {nd }}$ assessment & $48.1 \pm 16.1$ & $44.9 \pm 12.4$ & $50.1 \pm 18.2$ & 0.144 \\
\hline & Difference & 1.095 & -7.625 & 6.462 & \\
\hline & $p$ (ANOVA) & 0.763 & 0.022 & 0.227 & \\
\hline \multirow{4}{*}{$\begin{array}{l}\text { Tricuspid annular plane } \\
\text { systolic excursion (mm) }\end{array}$} & $1^{\text {st }}$ assessment & $19.4 \pm 1.9$ & $19.8 \pm 1.6$ & $19.2 \pm 2.1$ & 0.467 \\
\hline & $2^{\text {nd }}$ assessment & $20.8 \pm 1.3$ & $21.1 \pm 1.5$ & $20.6 \pm 1.2$ & 0.588 \\
\hline & Difference & 1.429 & 1.375 & 1.462 & \\
\hline & $p$ (ANOVA) & 0.000 & 0.045 & 0.004 & \\
\hline \multirow{4}{*}{ Relative wall thickness } & $1^{\text {st }}$ assessment & $0.28 \pm 0.03$ & $0.3 \pm 0.3$ & $0.28 \pm 0.03$ & 0.557 \\
\hline & $2^{\text {nd }}$ assessment & $0.27 \pm 0.02$ & $0.3 \pm 0.2$ & $0.27 \pm 0.03$ & 0.328 \\
\hline & Difference & -0.009 & -0.011 & -0.008 & \\
\hline & $p$ (ANOVA) & 0.012 & 0.17 & 0.033 & \\
\hline \multirow{4}{*}{$\begin{array}{l}\text { LV end-diastolic } \\
\text { diameter (mm) }\end{array}$} & $1^{\text {st }}$ assessment & $53.9 \pm 5.9$ & $54.5 \pm 5.2$ & $53.5 \pm 6.5$ & 0.711 \\
\hline & $2^{\text {nd }}$ assessment & $53.8 \pm 6.1$ & $55.5 \pm 4.9$ & $52.7 \pm 6.7$ & 0.041 \\
\hline & Difference & -0.143 & 1.0 & -0.85 & \\
\hline & $p$ (ANOVA) & 0.751 & 0.14 & 0.14 & \\
\hline
\end{tabular}


Thus, our study, like others, demonstrates that aging leads to both functional and structural changes at the cardiac level and that the implementation of a multidisciplinary intervention program can translate into significant noticeable changes in some of the echocardiographic parameters. Some authors ${ }^{35}$ also sustain that training may contribute to the maintenance of ventricular compliance throughout life, thus reducing the risk of developing heart failure.

According to Vigorito and Giallauria, ${ }^{39}$ intervention programs for the older population should be well planned and composed of different aspects, such as cognitive therapy, occupational therapy, balanced exercise plans, and nutritional and pharmacological counseling, thus promoting a healthier lifestyle. It is equally important to perform at least 30 minutes of exercise 4 or 5 times a week. ${ }^{40}$ Regarding the cardiovascular area, the Physical Activity Guidelines for Americans recommend regular 150-minute moderate-intensity, or 75-minute high-intensity exercise, to reduce the risk of coronary heart disease mortality. ${ }^{41}$

In our study, it was observed that the implementation of a multidisciplinary program (physical, nutritional and pharmacological intervention) in older individuals possibly led to some functional and, to a lesser extent, structural changes observed by echocardiography. These changes were more evident in the group practicing physical exercise. In fact, in the group that did not participate in the physical exercise component, there were only statistically significant changes between the 2 evaluation moments for the tricuspid valve maximum velocity of the A-wave and TAPSE.

An important issue in prescribing exercises adapted to the older population refers to the type of exercise to be employed (aerobic and/or endurance). The intervention program designed within the scope of this study included both aerobic and strength components, combined with balance exercises, applied according to individual needs and dynamically titrated according to the response over time. The benefits found at the cardiac level thus suggest a potential benefit of combined exercise models, in which the resisted element adds a determinant increase in muscle mass for the prevention of sarcopenia and the occurrence of falls. ${ }^{42}$ Recent studies have also identified combined exercise models (aerobic and endurance) as the most effective in promoting better neuromuscular and cardiorespiratory function in older adults. ${ }^{43,44}$ This may be explained by the differential benefit of these exercise modalities, since the aerobic component is important to improve the metabolic aspects, ${ }^{45}$ and the strength component is relevant to improve body composition and motor control. ${ }^{46,47}$
Limitations of the study and future perspectives

The small sample size and the use of convenience sampling, as well as the fact that the population studied is much older compared to previously published studies, may have conditioned the results. The loss of participants from the first to the second evaluation may also have adversely affected the results, mainly due to the reduction in statistical power resulting from the consequent reduction in sample size. This aspect prevented the use of more sophisticated statistical analysis methodologies. However, the existence of few available studies that investigate the effect of multidisciplinary intervention models, such as the one applied in the present study, in such old populations, reinforces the importance and originality of this research.

\section{CONCLUSION}

The results showed that physical exercise, adapted and implemented under a multidisciplinary intervention program, is a useful non-pharmacological tool for maintaining adequate cardiac function and structure in older adults. Considering that all participants included in the study benefited from the same intervention protocol, differing only in the physical exercise component, the identification of significant improvements only in the group with high adherence to the physical exercise program reinforces the particular utility of this component for the preservation of cardiovascular health in the older population.

A future challenge will be to understand whether multidisciplinary and personalized intervention approaches aimed at optimizing functionality and promoting overall quality of life in general, including actions such as adapted physical exercise and nutritional and therapeutic counseling, can be effective strategies to improve cardiovascular functionality, as well as to identify the risks that may be associated with it throughout life.

\section{CONFLICT OF INTERESTS}

There is no conflict of interest to declare.

\section{FINANCING}

This work is co-financed by the European Regional Development Fund (ERDF), through the Portugal 2020 Partnership Agreement - Regional Operation Program CENTRO 2020, under the project CENTRO-01-0145FEDER-023369AGA@4life:AGA - Comprehensive Geriatric approach to promote active and healthy aging - implementation of an integrated and multidisciplinary intervention program. 


\section{REFERENCES}

1. United Nations. Department of Economic and Social Affairs, Population Division. World Population Prospects: The 2015 Revision, Key Findings and Advance Tables. Working Paper NO.ESA/P/WP.241.2015. United Nations; 2015.

2. Lakatta EG. So! What's aging? Is cardiovascular aging a disease? J Mol Cell Cardiol. 2015;83:1-13. https://doi.org/10.1016/j.yjmcc.2015.04.005

3. Litvoc CJ, Brito FC, Barreto SM. Envelhecimento: prevenção e promoção da saúde. Conceitos básicos. São Paulo: Atheneu; 2004.

4. Fechine B, Trompieri N. O processo de envelhecimento: as principais alterações que acontecem com o idoso com o passar dos anos. Inter Science Place. 2012;20(1).

5. Feridooni HA, Dibb KM, Howlett SE. How cardiomyocyte excitation calcium release and contraction become altered with age. J Mol Cell Cardiol. 2015;83:62-72. https://doi.org/10.1016/j.yjmcc.2014.12.004

6. Wajngarten M. O coração no idoso. Diagnósticos Cardiologia. 2010;13(43).

7. Lakatta EG, Levy D. Arterial and Cardiac Aging: Major Shareholders in Cardiovascular Disease Enterprises. Circulation. 2003;107(2):346-54. https://doi.org/10.1161/01.cir.0000048893.62841.f7

8. Keller KM, Howlett SE. Sex differences in the Biology and Pathology of the Aging Heart. Can J Cardiol. 2016;32(9):1065-73. https://doi. org/10.1016/j.cjca.2016.03.017

9. Shioi H, Inuzuka Y. Aging as a substrate of heart failure. J Cardiol. 2012;60(6):423-8. https://doi.org/10.1016/j.jjcc.2012.07.015

10. Martins Júnior LM. 0 envelhecimento e o coração: as valvas. Rev Fac Ciênc Méd Sorocaba. 2016;18(1):58-9. https://doi.org/10.5327/ Z1984-4840201625388

11. Pomerance A. Ageing changes in human heart valves. Br Heart J. 1967;29(2):222-31. https://dx.doi.org/10.1136\%2Fhrt.29.2.222

12. New SE, Aikawa E. Cardiovascular calcification- An inflammatory disease. Circulation. 2011;75(6):1305-13. https://doi.org/10.1253/ circj.cj-11-0395

13. Ranasinghe I, Cheruvu C, Yiannikas J. Sigmoid Septum (SS): An Age Related Phenomenon or Sigmoid Hypertrophic Cardiomyopathy (sHCM)? Heart Lung Circulation. 2010;19(Suppl. 2):S53. https://doi. org/10.1016/j.hlc.2010.06.793

14. Oxenham H, Sharpe N. Cardiovascular aging and heart failure. Eur J Heart Fail. 2003;5(4):427-34. https://doi.org/10.1016/s13889842(03)00011-4

15. Sahasakul Y, Edwards WD, Naessens JM, Tajik AJ. Age-related changes in aortic and mitral valve thickness: implications for two-dimensional echocardiography based on an autopsy study of 200 normal human hearts. Am J Cardiol. 1988;62(7):424-30. https://doi.org/10.1016/00029149(88)90971-x

16. Masugata H, Senda S, Goda F, Yoshihara Y, Yoshihara K, Fujita N, et al. Cardiac Function as Assessed by Echocardiography in the Oldest Old $\geq 90$ Years of Age. Int Heart J. 2007;48(4):497-504. https://doi. org/10.1536/ihj.48.497

17. Cheitlin MD. Cardiovascular Physiology- Changes with Aging. Am J Geriatr Cardiol. 2003;12(1):9-13. https://doi.org/10.1111/j.10767460.2003.01751.x

18. Strait JB, Lakatta EG. Aging-associated cardiovascular changes and their relationship to heart failure. Heart Fail Clin. 2012;8(1):143-64. https://doi.org/10.1016/j.hfc.2011.08.011

19. Lakatta EG, Mitchell JH, Pomerance A, Rowe GG. Human aging: changes in structure and function. J Am Coll Cardiol. 1987;10(2 Suppl. A):42A-47A. https://doi.org/10.1016/s0735-1097(87)80447-3

20. Alvis BD, Hughes CG. Physiology Considerations in the Geriatric Patient. Anesthesiol Clin. 2015;33(3):447-56. https://doi.org/10.1016/j. anclin.2015.05.003

21. Gerstenblith G, Frederiksen J, Yin FC, Fortuin NJ, Lakatta EG, Weisfeldt ML. Echocardiographic Assessment of a Normal Adult Aging Population. Circulation. 1977;56(2):273-8. https://doi.org/10.1161/01.cir.56.2.273

22. Levy D, Garrison RJ, Savage DD, Kannel WB, Castelli WP. Prognostic implications of echocardiographically determined left ventricular mass in the Framingham Heart Study. N Engl J Med. 1990;322(22):1561-6. https://doi.org/10.1056/NEJM199005313222203
23. Lakatta EG. Do hypertension and aging have a similar effect on the myocardium? Circulation. 1987;75(1 Pt 2):169-77.

24. Platt C, Houstis N, Rosenzweig A. Using Exercise to Measure and Modify Cardiac Function. Cell Metab. 2015;21(2):227-36. https:// dx.doi.org/10.1016\%2Fj.cmet.2015.01.014

25. Jakovljevic DG. Physical activity and cardiovascular aging: Physiological and molecular insights. Exp Gerontol. 2018;109:67-74. https://doi. org/10.1016/j.exger.2017.05.016

26. Eijsvogels TM, Molossi S, Lee D, Emery MS, Thompson PD. Exercise at the Extremes: The Amount of Exercise to Reduce Cardiovascular Events. J Am Coll Cardiol. 2016;67(3):316-29. https://doi.org/10.1016/j. jacc.2015.11.034

27. Lang RM, Badano LP, Mor-Avi V, Afilalo J, Armstrong A, Ernande $L$, et al. Recommendations for Cardiac Chamber Quantification by Echocardiography in Adults: An Update from the American Society of Echocardiography and the European Association of Cardiovascular Imaging. J Am Soc Echocardiogr. 2015;28(1):1-39.e14. https://doi. org/10.1016/j.echo.2014.10.003

28. Mitchell C, Rahko PS, Blauwet LA, Canaday B, Finstuen JA, Foster MC, et al. Guidelines for Performing a Comprehensive Transthoracic Echocardiographic Examination in Adults: Recommendations from the American Society of Echocardiography. J Am Soc Echocardiogr. 2019;32(1):1-64. https://doi.org/10.1016/j.echo.2018.06.004

29. Guirado GN, Damatto RL, Matsubara BB, Roscani MG, Fusco DR, Cicchetto LA, et al. Combined exercise training in asymptomatic elderly with controlled hypertension: effects on functional capacity and cardiac diastolic function. Med Sci Monit. 2012;18(7):R461-5. https://doi.org/10.12659/msm.883215

30. Galetta F, Franzoni F, Femia FR, Bartolomucci F, Carpi A, Santoro G. Left ventricular diastolic function and carotid artery wall in elderly athletes and sedentary controls. Biomed Pharmacother. 2004;58(8):437-42. https://doi.org/10.1016/j.biopha.2004.08.008

31. Jungblut PR, Osborne JA, Quigg RJ, McNeal MA, Clauser J, Muster AJ, et al. Echocardiographic Doppler evaluation of left ventricular diastolic filling in older, highly trained male endurance athletes. Echocardiography. 2000;17(1):7-16. https://doi.org/10.1111\%2Fj.1540-8175.2000. tb00988.x

32. Nottin S, Nguyen LD, Terbah M, Obert P. Long-term endurance training does not prevent the agerelated decrease in left ventricular relaxation properties. Acta Physiol Scand. 2004;181(2):209-15. https://doi. org/10.1111/j.1365-201X.2004.01284.x

33. Suboc TB, Strath SJ, Dharmashankar K, Harmann L, Couillard A, Malik $\mathrm{M}$, et al. The impact of moderate intensity physical activity on cardiac structure and performance in older sedentary adults. Int J Cardiol Heart Vessels. 2004;4:19-24. https://doi.org/10.1016/j.ijchv.2014.08.007

34. Fujimoto N, Prasad A, Hastings JL, Arbab-Zadeh A, Bhella PS, Shibata $S$, et al. Cardiovascular effects of 1 year of progressive and vigorous exercise training in previously sedentary individuals older than 65 years of age. Circulation. 2010;122(18):1797-805. https://doi.org/10.1161/ CIRCULATIONAHA.110.973784

35. Arbab-Zdeh A, Dijk E, Prasad A, Fu Q, Torres P, Zhang R, et al. Effect of Aging and Physical Activity on Left Ventricular Compliance. Circulation. 2004;110(13):1799-805. https://doi.org/10.1161/01. CIR.0000142863.71285.74

36. Haykowsky M, McGavock J, Muhll IV, Koller M, Mandic S, Welsh R, et al. Effect of exercise training on peak aerobic power, left ventricular morphology, and muscle strength in healthy older women. J Gerontol A Biol Sci Med Sci. 2005;60(3):307-11. https://doi.org/10.1093/ gerona/60.3.307

37. Gates PE, Tanaka H, Graves J, Seals DR. Left ventricular structure and diastolic function with human ageing. Eur Heart J. 2003;24(24):2213-20. https://doi.org/10.1016/j.ehj.2003.09.026

38. Prasad A, Popovic ZB, Arbab-Zadeh A, Fu Q, Palmer D, Dijk E, et al. The effects of aging and physical activity on Doppler measures of diastolic function. Am J Cardiol. 2007;99(12):1629-36. https://doi. org/10.1016/j.amjcard.2007.01.050

39. Vigorito C, Giallauria F. Effects of exercise on cardiovascular performance in the elderly. Front Physiol. 2014;5:51. https://doi.org/10.3389/ fphys.2014.00051 
40. Bhella PS, Hastings JL, Fujimoto N, Shibata S, Carrick-Ranson G, Palmer MD, et al. Impact of lifelong exercise "dose" on left ventricular compliance and distensibility. J Am Coll Cardiol. 2014;64(12):1257-66. https://doi.org/10.1016/j.jacc.2014.03.062

41. U.S. Department of Health and Human Services. Physical Activity Guidelines for Americans. Report. Washington, D.C.: U.S. Department of Health and Human Services; 2008.

42. Yoo SZ, No MH, Heo JW, Park D-H, Kang J-H, Kim SH, et al. Role of exercise in age-related sarcopenia. J Exerc Rehabil. 2018;14(4):551-8. https://dx.doi.org/10.12965\%2Fjer.1836268.134

43. Bann D, Chen H, Bonell C, Glynn NW, Fielding RA, Manini T, et al. Socioeconomic differences in the benefits of structured physical activity compared with health education on the prevention of major mobility disability in older adults: the LIFE study. J Epidemiol Community Health. 2016;70(9):930-3. https://doi.org/10.1136/ jech-2016-207321
44. Sbardelotto ML, Costa RR, Malysz KA, Pedroso GS, Pereira BC, Sorato $\mathrm{HR}$, et al. Improvement in muscular strength and aerobic capacities in elderly people occurs independently of physical training type or exercise model. Clinics (São Paulo). 2019;74:e833. http://doi.org/10.6061/ clinics/2019/e833

45. Izquierdo M, Ibañez J, HAkkinen K, Kraemer WJ, Larrión JL, Gorostiaga EM. Once weekly combined resistance and cardiovascular training in healthy older men. Med Sci Sports Exerc. 2004;36(3):435-43. https:// doi.org/10.1249/01.mss.0000117897.55226.9a

46. Seene T, Kaasik P. Role of Myofibrillar Protein Catabolism in Development of Glucocorticoid Myopathy: Aging and Functional Activity Aspects. Metabolites. 2016;6(2). https://doi.org/10.3390/metabo6020015

47. Sharples AP, Stewart CE, Seaborne RA. Does skeletal muscle have an 'epi'-memory? The role of epigenetics in nutritional programming, metabolic disease, aging and exercise. Aging Cell. 2016;15(4):603-16. https://doi.org/10.1111/acel.12486 